[Vicino Oriente XIX (2015), pp. 97-111]

\title{
PRELIMINARY NOTES ON THE WARE DEPICTED ON THE CEILING OF THE CAPPELLA PALATINA IN PALERMO
}

\author{
Ida Materia - “L’Orientale” University of Naples*
}

This essay is an attempt to classify the ware depicted on the Cappella Palatina ceilings in Palermo (mid-12 $2^{\text {th }}$ century). 250 artefacts have been identified (glasses, bowls, bottles, jugs, and candlesticks), but due to the deterioration of some paintings and the unavailability of good reproductions only 230 items could be drawn. It is impossible to detect with certainty what material the ware was made of, while the decorative technique can only be hypothesised in a few instances. The comparison of some ware depicted on the ceiling of an aisle with later artefacts may support the hypothesis of dating the aisle paintings (or some of them) to a later period.

Keywords: Palermo; Cappella Palatina; painted ceiling; Islamic context; ware

The Cappella Palatina in Palermo was commissioned by Roger II as soon he was crowned King of Sicily in 1130. It was consecrated on 28 April 1140, and its construction ended three years later.

The chapel consists of two distinct architectonic parts, namely a circular presbytery rising above the ground, and a three-aisled longitudinal building. ${ }^{1}$ The wooden ceiling of the latter is entirely painted.

As for the objects depicted on the ceiling, two studies have been carried out thus far: one devoted to musical instruments, ${ }^{2}$ and the other to the textiles and garments worn by the characters represented. ${ }^{3}$ A third category of subjects, so far neglected, consists of ware (glasses, bowls, bottles, and jugs), which are mostly found in court scenes. This study will focus on this topic.

\section{WARE IDENTIFICATION AND LOCATION}

The preliminary work of identifying and mapping the ware was based on the photographic repertory and maps published by Beat Brenk, ${ }^{4}$ and on the photographs of the ceilings of the aisles taken by Francesca Anzelmo, ${ }^{5}$ to whom I am very grateful.

250 artefacts have been identified, 189 on the nave ceiling and 61 on the aisle ceilings. They consist of: 85 glasses, 9 goblets, 31 small bowls, 9 bowls, 2 bacini, 1 large bowl, 1 dish, 51 bottles, 53 jugs, 6 beakers/flasks and 2 candlesticks.

* This article presents a summary of my unpublished MA Thesis "Il corpus del vasellame riprodotto sul soffitto ligneo dipinto della Cappella Palatina di Palermo” (Sapienza University of Rome, January 2014), which the catalogue numbers given in the text refer to. The development of this topic is the subject of my current PhD thesis (University of Naples “L’Orientale”). This paper was translated into English by Dr Michelina Di Cesare to whom I want to express my gratitude.

1 Ćurčić 1987, 125-144; Brenk 2010, 27-78; Tronzo 2010, 79-85; Anzelmo 2012-2013, 14-15.

2 Gramit 1985; 1986.

Anzelmo 2012-2013.

4 Brenk ed. 2010.

5 Anzelmo 2012-2013. 
The map in fig. 1 shows the location of the ware on the octagonal small domes - the core of the ceiling - and the framing muqarnas. The map has been re-drawn after the one published by Brenk. ${ }^{6}$

Nave. The ware is found on the 'petals' of six of the small octagonal domes, and on all the muqarnas except for one.

Aisles. The ware is found in the 48 ceiling coffers (fig. 2).

\section{DRAWINGS OF THE WARE}

The drawings were obtained from the photographs by using a vector program. The classification of the corpus is based on them.

It was not possible to draw all the identified and mapped artefacts due to the deterioration of some paintings and the unavailability of good reproductions useful to obtain a drawing. Consequently, out of the 250 identified items only 230 were drawn. The 20 unreproducible items are 10 glasses, 1 bowl, 5 bottles, and 4 jugs depicted on the nave ceiling.

The dimensions of the ware were deduced through a proportional method applied to the ratio between the depicted object and the hands of the human figures. The hands holding the ware or in proximity to it were considered units of measurement. This method allowed the ware to be scaled down with a good degree of reliability.

The hands belong to male characters except in one case: the dancing girls depicted on the ceiling of the nave. The male characters hold a ware (figs. 3:a, 10:a, 13:a, 15:a), or play a musical instrument, or make a gesture consisting of the index finger stretching forward while the other fingers are bent.

This characteristic means these three gestures can be taken as conventional models for comparison. The male hand was scaled down by using the average dimensions of a male hand; likewise the hands of the female dancers.

The first gesture to be analysed, which is the most recurrent, is that of a hand holding a glass or a small bowl or flask. If we draw a straight line from the thumb to the middle finger of an average male hand (fig. 3:a-b), it will measure $10 \mathrm{~cm}$. According to this scale $10 \mathrm{~cm}$ correspond to $3.2 \mathrm{~cm}$ in the reproduction. By applying the resulting proportion it was possible to obtain, to a good approximation, the dimensions of the ware depicted in each scene.

This very method was used for the remaining cases:

- hand playing a musical instrument: real dimension $12 \mathrm{~cm}$, dimension in the photograph $3.8 \mathrm{~cm}(10: 12=3.2: 3.8)$;

- hand with the index finger stretched forward: real dimension $11 \mathrm{~cm}$, dimension in the photograph $3.5 \mathrm{~cm}(10: 11=3.2: 3.5)$.

The hands of the two female dancers are depicted differently from those of the male characters. In one case they are represented in profile, and in another the back of the hand is fully visible. The dimensions obtained are the following:

- hand seen in profile: the real thickness of a hand section is $4 \mathrm{~cm}$, the thickness of the hand in the photograph is $2 \mathrm{~cm}(4: 8=2: 4)$;

$6 \quad$ Brenk ed. 2010, IV, 393. 
XIX (2015) Preliminary notes on the ware depicted on the ceiling of the Cappella Palatina in Palermo

- hand seen from the back: the real width of the back of a hand is $8 \mathrm{~cm}$, the width of the back of the hand in the photograph is $4 \mathrm{~cm}(4: 8=2: 4)$.

\section{SHAPES OF THE CLASSIFIED WARE (230 ITEMS)}

Being incorporated in court-related contexts the ware depicted on the ceiling of the Palatina probably reproduces mostly objects made of glass or metal, but in some cases such as those of the bacini (cat. 124-125) - the objects could be made out of ceramic.

The artefacts were classified according to their shapes: open forms (127 items), closed forms (95 items), and uncertain forms (8 items).

\subsection{Open forms (127 items; figs. 4-6)}

Among the open forms, 75 glasses (cat. 1-75; fig. 4), 9 goblets (cat. 76-84; fig. 5), 30 small bowls (cat. 85-114; fig. 5), 9 bowls (cat. 115-123; fig. 6), 2 bacini (cat. 124-125; fig. 6), 1 large bowl (cat. 126; fig. 6) and 1 dish (cat. 127; fig. 6) were identified.

The open forms have a convex base except for the bowls, the bacini, the large bowl, and 13 glasses (cat. 3-5, 7, 9, 29-30, 40, 54-57, 69).

Most of the glasses, goblets and small bowls are footless, one glass is fashioned as a chalice (cat. 73), two goblets (cat. 83 and 84) present a peduncle, and a small bowl (cat. 109) exhibits a splayed foot. The bowls, bacini, and large bowl present a splayed foot, except for two bowls, one of which is footless (cat. 123) and the other (cat. 117) has a peduncle.

The sides are flared, rounded, or vertical. An exception consists of an item (cat. 9) with a truncated pyramidal shape. A group of phial-shaped glasses was also identified. These glasses are distinguished by a very elongated body (cat. 5, 7, 29-30, 40, 54-57 and 69).

The sides of the open forms are straight or flared.

\subsection{Closed forms (95 items; figs. 7-8)}

Among the closed forms 46 bottles (cat. 128-173; fig. 7) and 49 jugs (cat. 174-222; fig. 8) were identified.

Most of their bodies are globular, globular but elongated, or pyriform. Only one object presents a carinated body (cat. 156).

The necks have cylindrical (cat. 128, 131-133, 135-136, 140, 143, 149, 159, 161, 163, $165,167,172-173$ ) or flared shapes (cat. 129-130, 137, 144-147, 157, 168, 170); in 16 instances they are encircled by a collar (cat. 134, 139, 141-142, 148, 151-152, 154-156, 158, 160, 162, 164, 169, 171). Four items end with flared lips (cat. 150, 155, 166, 171), and one has an oblique shoulder (cat. 162).

\subsection{Uncertain forms (8 items; fig. 9)}

Among the objects which cannot be classified (§ 3.2.) with absolute certainty are six globular beakers/flasks (cat. 223-228) and two probable candlesticks with concave bases (cat. 229-230). 


\section{DECORATION}

It is impossible to detect with certainty which material the ware was supposed to be made of, also in cases that seem more evident, while the decorative technique can be hypothesised, to a good approximation, in just a few instances. Therefore, it was deemed more suitable to group the objects according to the distribution of the ornamentation on the different shapes rather than to provide an effective classification.

22 types of motifs were identified. These can appear singularly, or two, three, or four of them can be combined with each other, thus originating 60 motifs found on 182 of the 230 drawn artefacts; 48 are not decorated.

The most recurrent ornamentation consists of a single small horizontal band instances), ${ }^{7}$ which is often combined with other motifs.

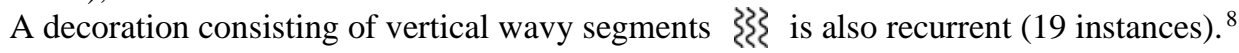

In decreasing order of appearance and considering only motifs occurring at least on 9 artefacts, combined decorations consisting of palmettes and small bands $=$ (12 instances), ${ }^{9}$ and small bands, small bands with palmettes, and wavy segments

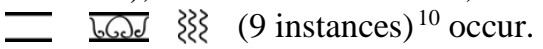

These motifs are associated with specific shapes of ware as follows:

- The so-called cintamani decoration $\bullet$ is chiefly depicted on closed forms, some bowls, and two goblets.

- Decorations consisting of short vertical segments, vertical wavy segments, horizontal -

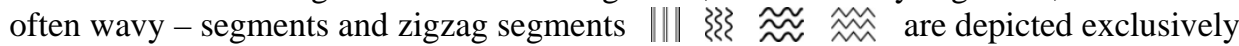
on glasses, goblets, and small bowls and are very recurrent.

- Decoration consisting of palmettes and/or semi-palmettes $\hookrightarrow \checkmark$ often occurs on small bowls and presents particularly elaborate ornamental developments.

\section{MORPHOLOGICAL AND DECORATIVE COMPARISONS}

A comparison with ware characterized by morphologies, decoration and dimensions similar to those appearing in the ware depicted on the ceiling of the Cappella Palatina will be useful especially to hypothesize which materials the objects represented there could be made of.

Undoubtedly, in some instances quite precise comparisons can be made. Among others it is worth mentioning a glass (north aisle, cat. 62; height $12.54 \mathrm{~cm}$, rim diameter $12.5 \mathrm{~cm}$; fig. 10:a-b), which can be compared to the ceramic item ascribed to $12^{\text {th }}$-century Iran (see, for instance, the exemplar kept in the Nasser D. Khalili Collection of Islamic Art, in London; ${ }^{11}$ fig. 11).

\footnotetext{
Glasses cat. 6-7; candlestick cat. 229; bottles cat. 140-156; jug cat. 181-189

Glasses cat. 9-12; goblets cat. 79-80; small bowls cat. 94-101, 103-107.

Bottles cat. 158-162; jugs cat. 199-205.

Bottles cat. 59-67.

1 Grube 1994, cat. 203 (INV РОT800; height $12 \mathrm{~cm}$, rim diameter 12 cm).
} 
XIX (2015) Preliminary notes on the ware depicted on the ceiling of the Cappella Palatina in Palermo

As for the ware occurring in coeval painted representations and found in the same area, a comparison with the ware reproduced on the wooden ceiling of Cefalù Cathedral, above all glasses, bottles, and jugs, is particularly interesting. ${ }^{12}$

Another intriguing comparison can be made with two artefacts reproduced on the famous "Baptistère de Saint Louis" (first half of the $14^{\text {th }}$ century; fig. 12). ${ }^{13}$ These are a glass with a peduncle and a bottle which present remarkable analogies with two goblets (nave, cat. 83-84; both height $17.18 \mathrm{~cm}$, rim diameter $13.43 \mathrm{~cm}$; fig. 13:a-b) and a bottle (nave, cat. 157; height $43.05 \mathrm{~cm}$, diameter maximum $22 \mathrm{~cm}$; fig. 14:a-b) depicted on the ceiling of the Palatina. In this case the ware reproduced on the Baptistère should not necessarily be considered as coeval to it but as preceding it.

However, among other instances, it is worth making a comparison with objects datable to the post-Norman period. Indeed, two glasses (northern aisle, cat. 55-56; height 18.41 and $20.52 \mathrm{~cm}$; rim diameter 10.94 and $14.37 \mathrm{~cm}$, respectively; fig. 15:a-b) show similarities with a well-known class of Ayyubid or Mamluk glasses $\left(13^{\text {th }}-14^{\text {th }}\right.$ century; fig. 16$) .{ }^{14}$ The presence of this kind of ware in the paintings found in the ceiling of one of the aisles could support a possible hypothesis of dating the paintings of the aisles (or some of them) to a later period. ${ }^{15}$

\section{REFERENCES}

ANZELMo, F.

2012-2013 I soffitti dipinti della Cappella Palatina di Palermo e l'orizzonte mediterraneo, PhD Diss., Tuscia University of Viterbo, Viterbo 2012-2013.

Aurigemma, M.G.

2004 Il cielo stellato di Ruggero II. Il soffitto dipinto della cattedrale di Cefalù, Milano 2004.

BRENK, B.

2010 L’importanza e la funzione della Cappella Palatina di Palermo nella storia dell'arte: B. Brenk (ed), La Cappella Palatina a Palermo (Mirabilia Italiae 17), I vol., Modena 2010, pp. 27-78.

BRENK, B. (ed.)

2010 La Cappella Palatina a Palermo (Mirabilia Italiae 17), 4 vols, Modena 2010.

ĆURČIĆ, S.

1987 Some Palatine Aspects of the Cappella Palatina in Palermo: Dumbarton Oaks Papers 41

GRAMIT, D. (1987), pp. 125-144.

1985 The Music Paintings of the Cappella Palatina in Palermo: Imago musicae 2 (1985), pp. 949

12 See Aurigemma 2004, especially figs. 85, 112, 113, 115-117, 126, 128, 130, and the b/w plates.

13 The Baptistère de Saint Louis is kept at the Louvre Museum in Paris, Ancien trésor de la chapelle du château de Vincennes, LP 1 (Rice 1951, pls. V, XXI).

14 See for example the items housed in London, The Nasser D. Khalili Collection of Islamic Art, inv. Nos. GLS 578a, 578b, and 578c (Nassar 2001, figs. 199-201); height 18, 15.8 and $12.5 \mathrm{~cm}$; rim diameter 12.7, 11.4 and $8.4 \mathrm{~cm}$, respectively.

15 Even Johns (2010, 391, 397, 429), who is among the few scholars maintaining that the nave and the aisles were not painted at the same time, however, proposes dating the aisles to not after 1180 . 
1986 I dipinti musicali della Cappella Palatina di Palermo (Scrinium, quaderni ed estratti di Schede Medievali 10), Palermo 1986.

GRUBE, E.J.

1994 Cobalt and Lustre: The First Centuries of Islamic Pottery (The Nasser D. Khalili Collection of Islamic Art 9), New York 1994.

JOHNS, J.

2010 Le pitture del soffitto della Cappella Palatina: B. Brenk (ed.), La Cappella Palatina a Palermo (Mirabilia Italiae 17), I vol., Modena 2010, pp. 387-407.

NASSAR, N.

2001 Trois gobelets: S. MAKARIOU, L'Orient de Saladin, l'art des Ayyoubides, exposition présentée à l'Institut du monde arabe, Paris, du 23 octobre 2001 au 10 mars 2002, Paris 2001, p. 190.

RICE, D.S.

1951 Le Baptistère de Saint Louis, Paris 1951.

TRONZO, W.

2010 L'architettura della Cappella Palatina: B. BRENK (ed.), La Cappella Palatina a Palermo (Mirabilia Italiae 17), I vol., Modena 2010, pp. 79-99. 

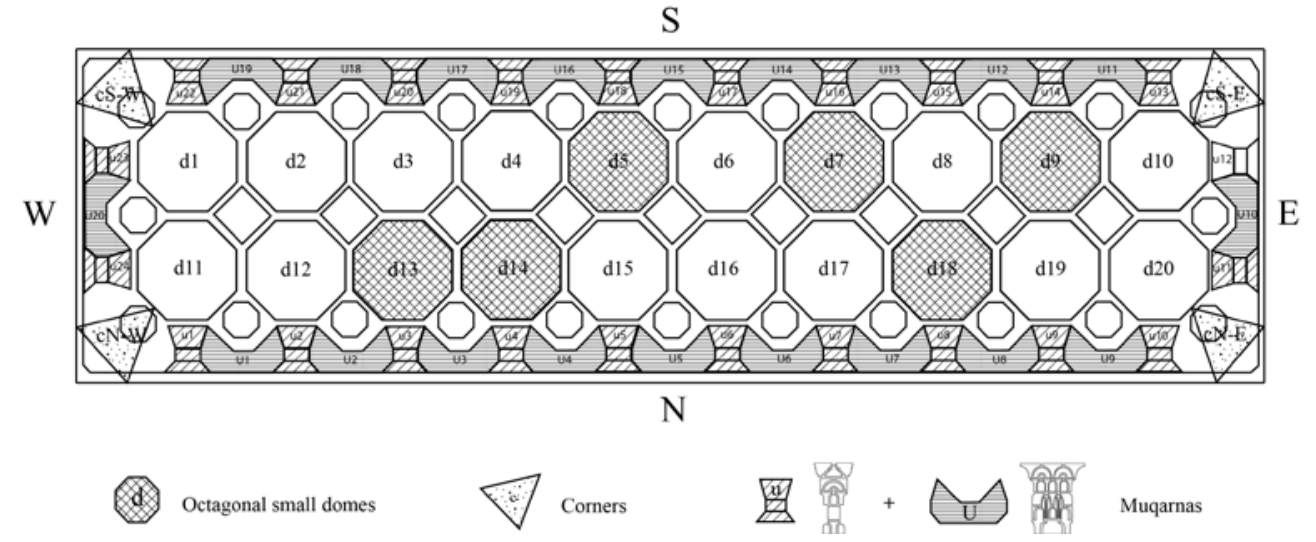

Fig. 1 - Palermo, Cappella Palatina, map of ware depicted on the nave ceiling.

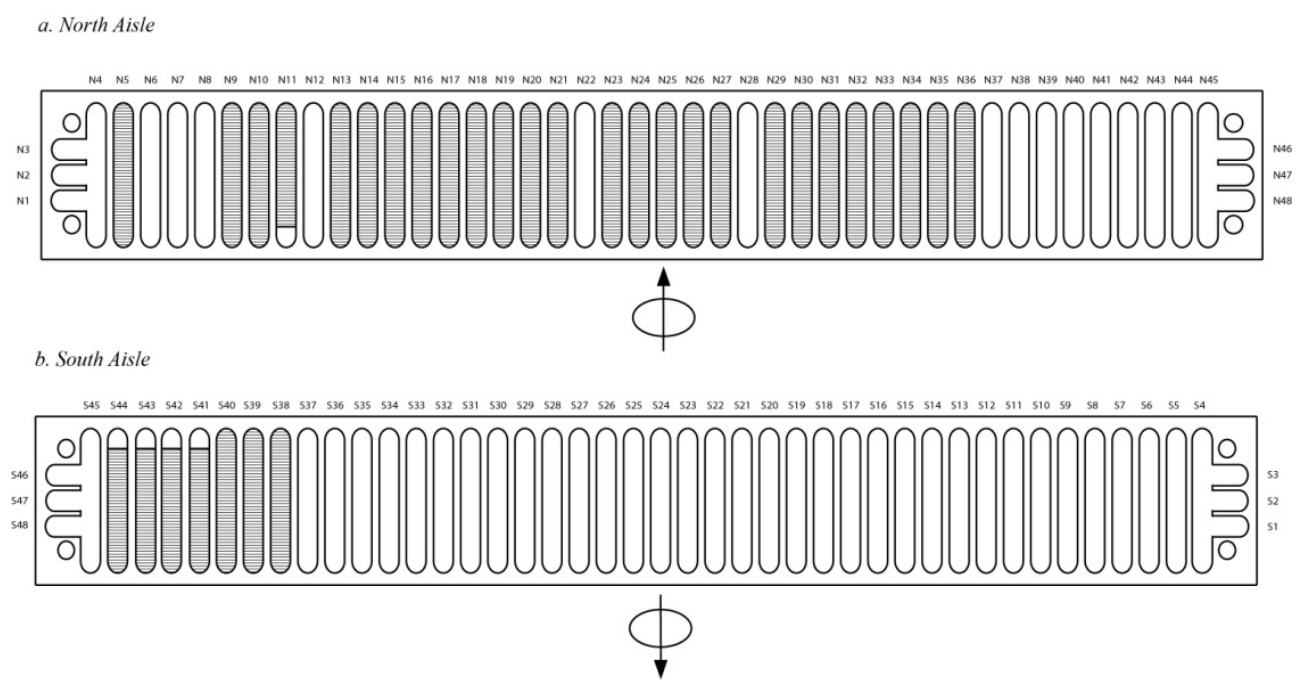

Original paintings

Fig. 2 - Palermo, Cappella Palatina, map of the ware depicted on the ceilings of the north and south aisles. 

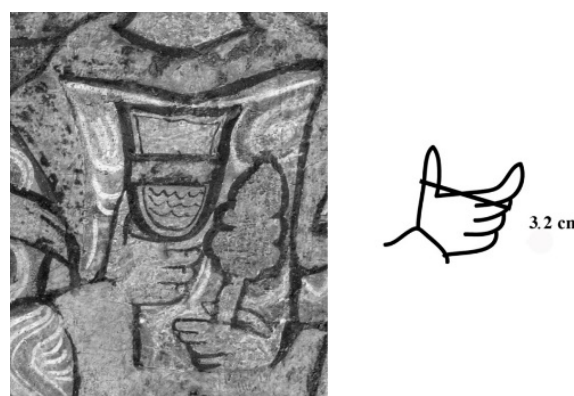

Fig. 3a-b - Glass cat. 52, nave. Detail from the original painting (left; after Brenk 2010, fig. 920) and a drawing (right) indicating the distance in a straight line between the thumb and the middle finger of an average male hand.
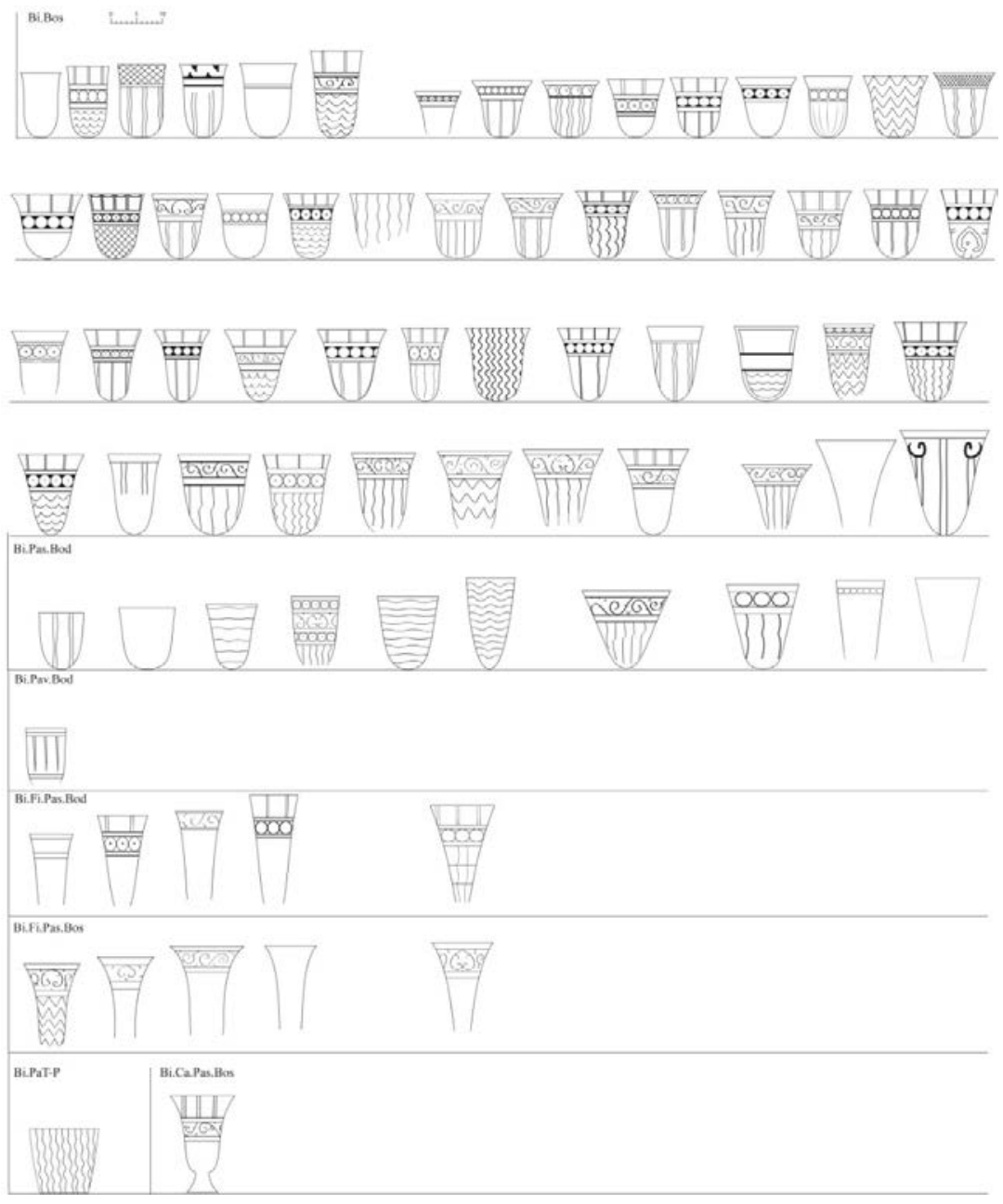

Fig. 4 - Glasses cat. 1-75. 
XIX (2015) Preliminary notes on the ware depicted on the ceiling of the Cappella Palatina in Palermo
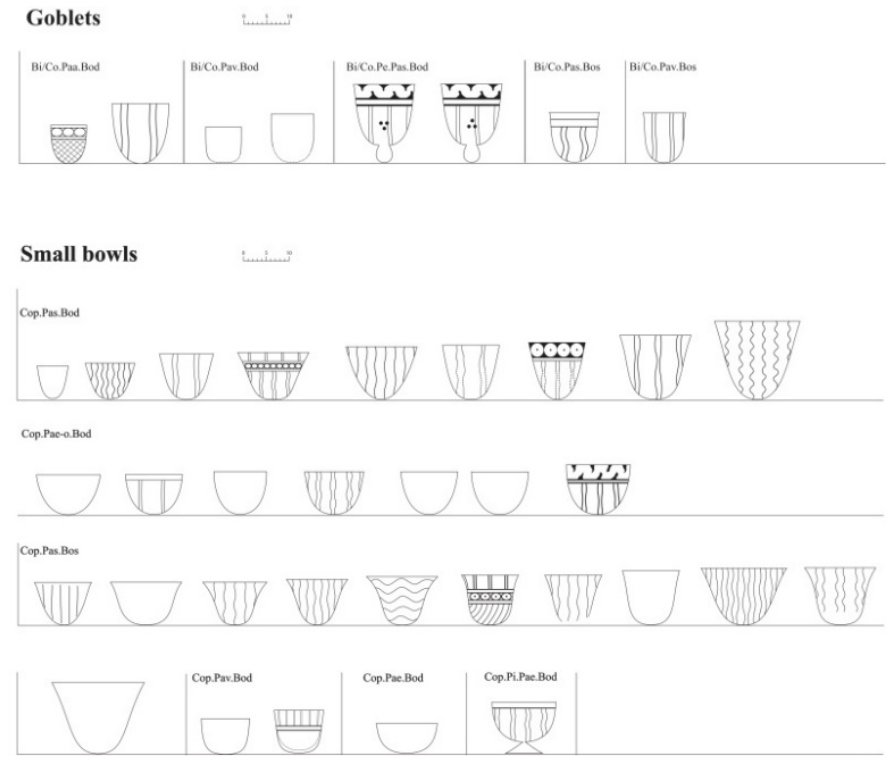

Fig. 5 - Goblets cat. 76-84 and small bowls cat. 85-114.

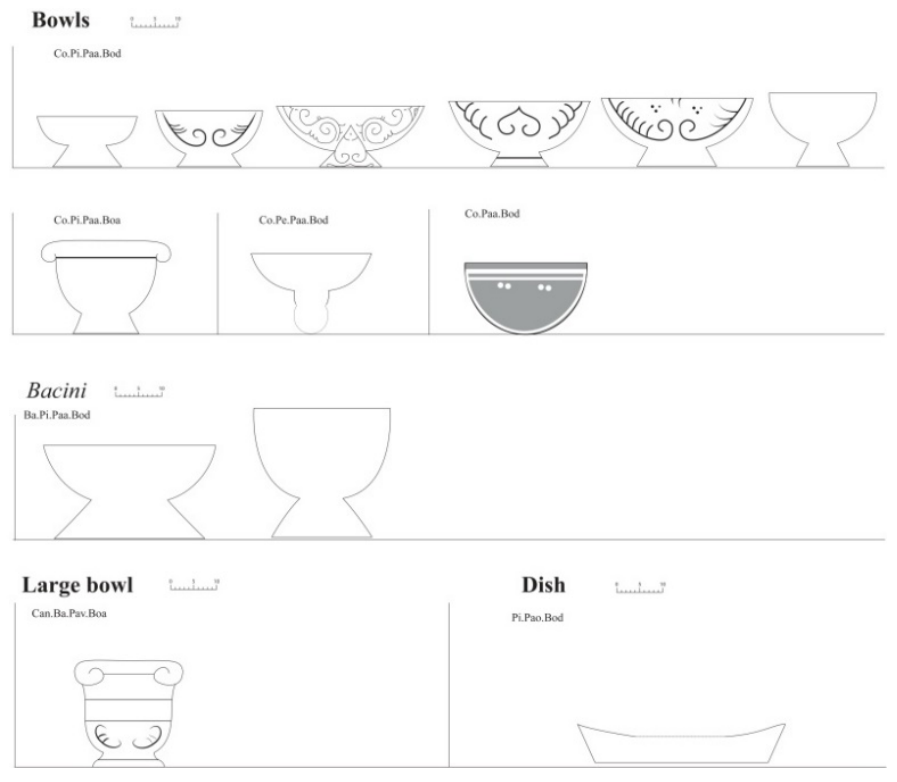

Fig 6 - Bowls cat. 115-123, bacini, cat. 124-125, large bowl cat. 126 and one dish cat. 127. 


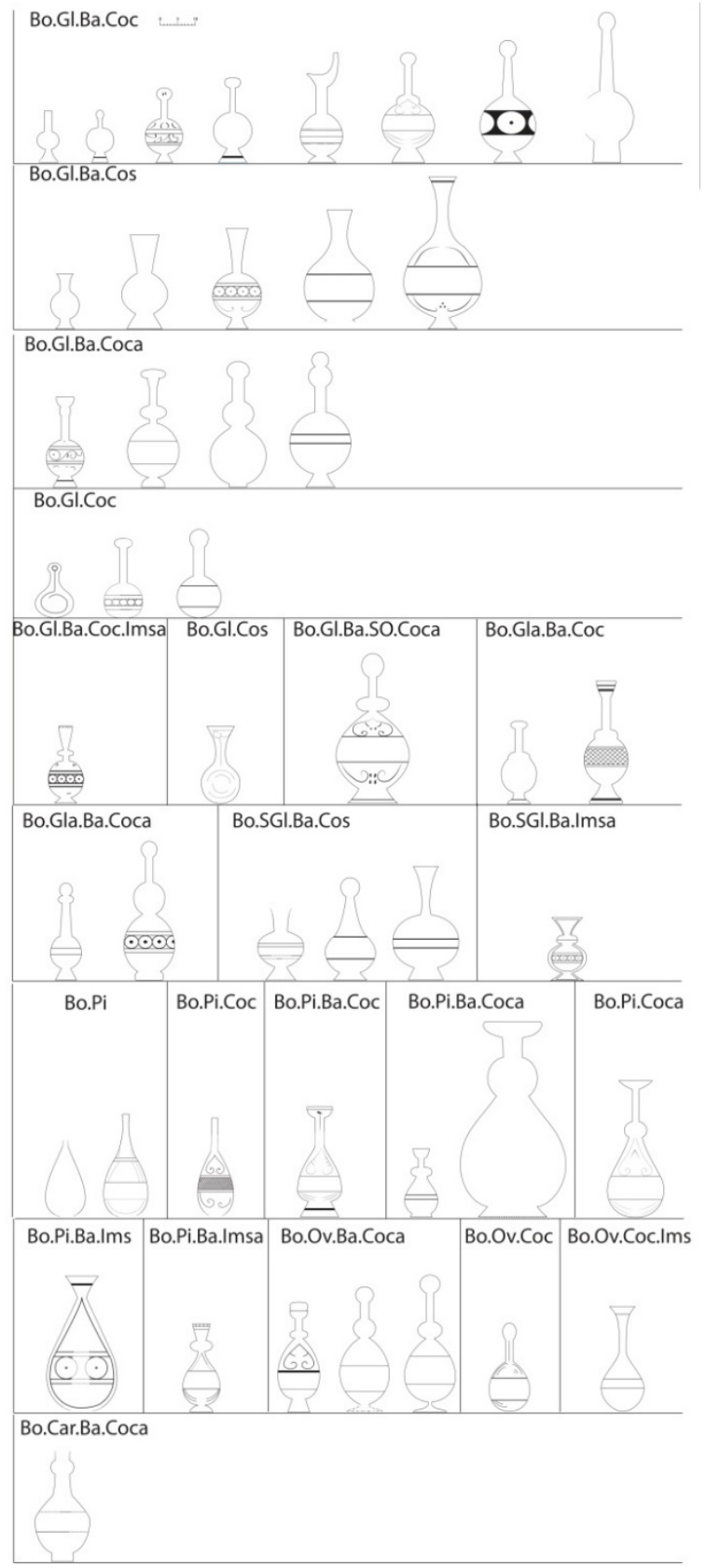

Fig. 7 - Bottles cat. 128-173. 
XIX (2015) Preliminary notes on the ware depicted on the ceiling of the Cappella Palatina in Palermo

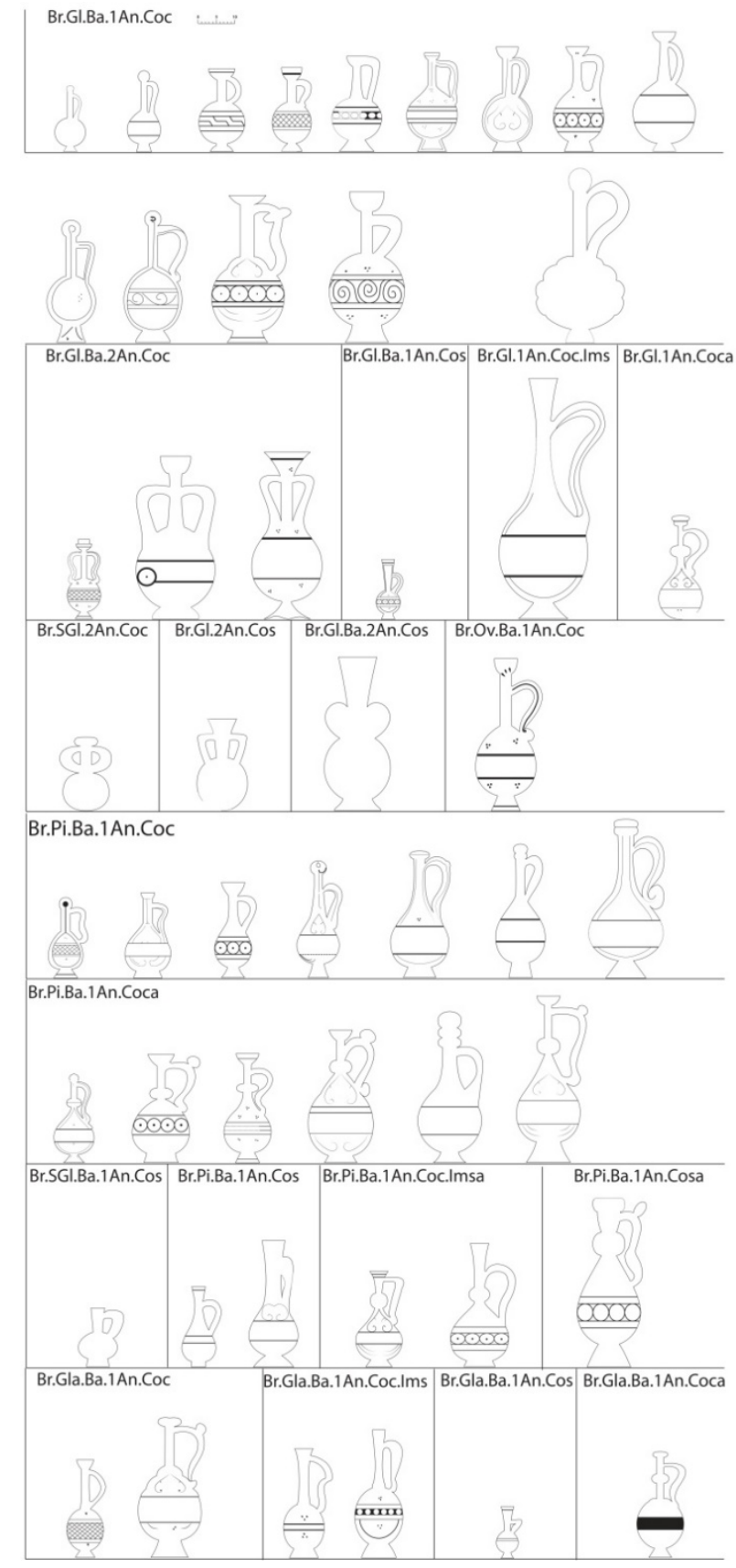

Fig. 8 - Jugs cat. 174-222. 


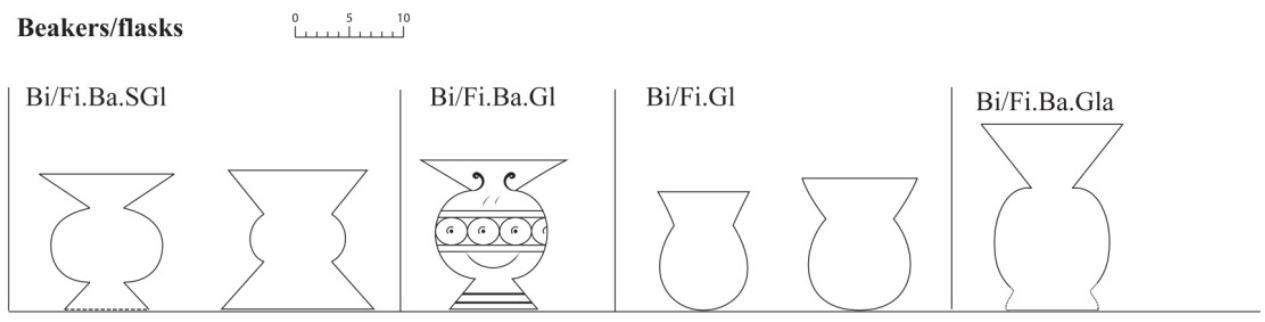

Candlesticks $\quad \overbrace{}^{0} \mathfrak{5}^{5}$ ل $^{10}$

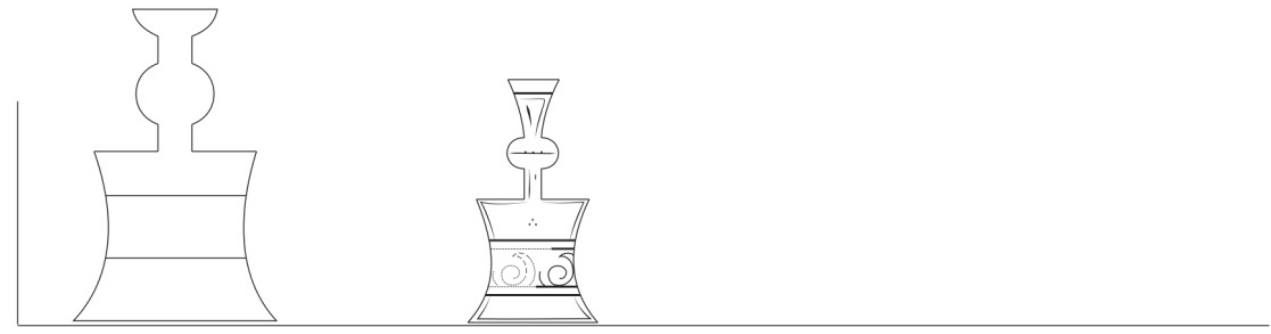

Fig. 9 - Beakers/flasks cat. 223-228 and candlesticks (?) cat. 229-230.
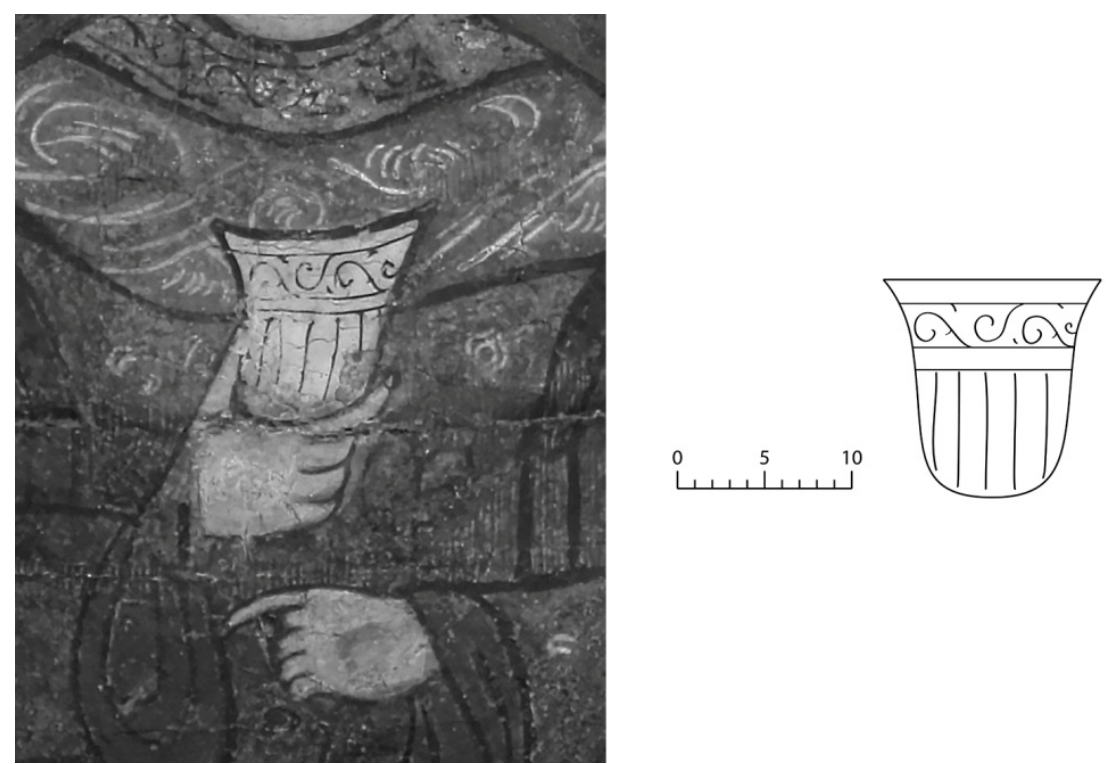

Fig. 10a-b - Glass cat. 62, north aisle. Detail from the original painting (left; photo (C) Francesca Anzelmo) and drawing (right). 
XIX (2015) Preliminary notes on the ware depicted on the ceiling of the Cappella Palatina in Palermo

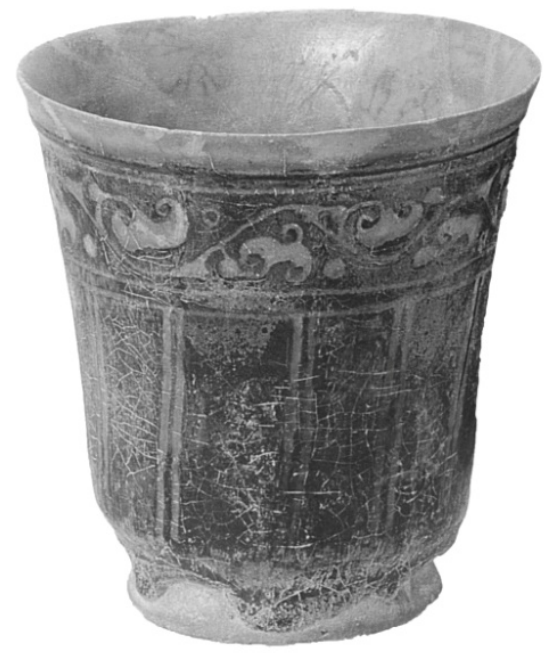

Fig. 11 - Ceramic goblet, Iran, $12^{\text {th }}$ century, London, The Nasser D. Khalili Collection of Islamic Art, Inv. POT 800 (after Grube 1994, cat. 203).

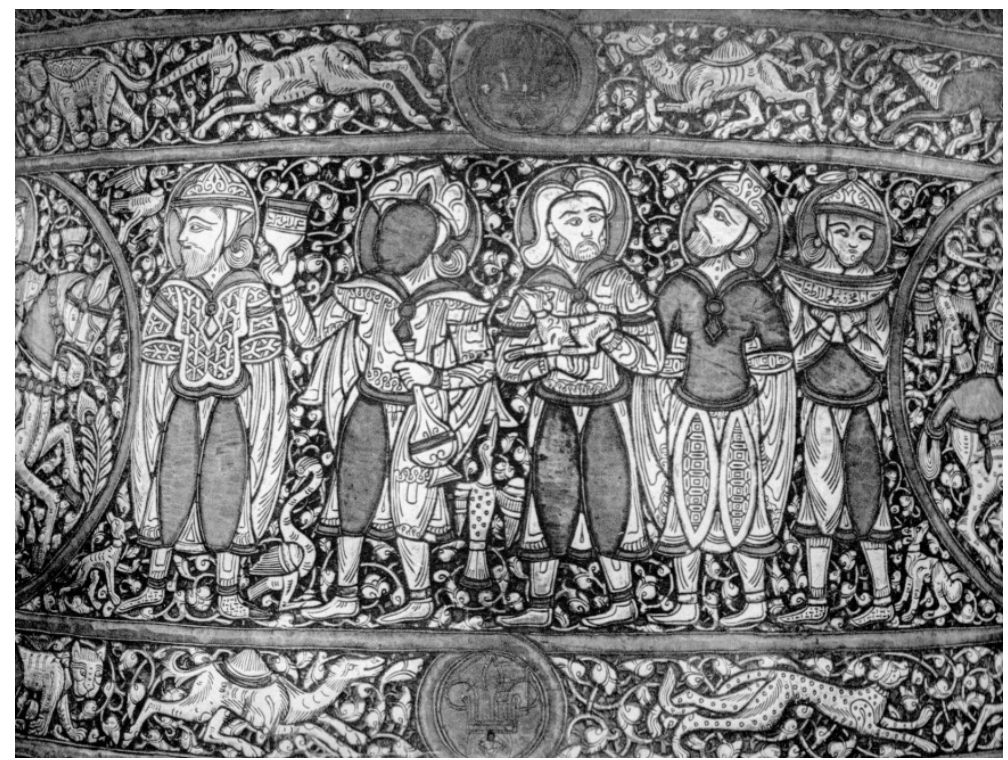

Fig. 12 - Artefacts depicted on the "Baptistère de Saint Louis”, Syria-Egypt, first half of the $14^{\text {th }}$ century, Paris, Louvre Museum, Ancien trésor de la chapelle du château de Vincennes, LP 1 (after Rice 1951, pl. XXI, detail). 


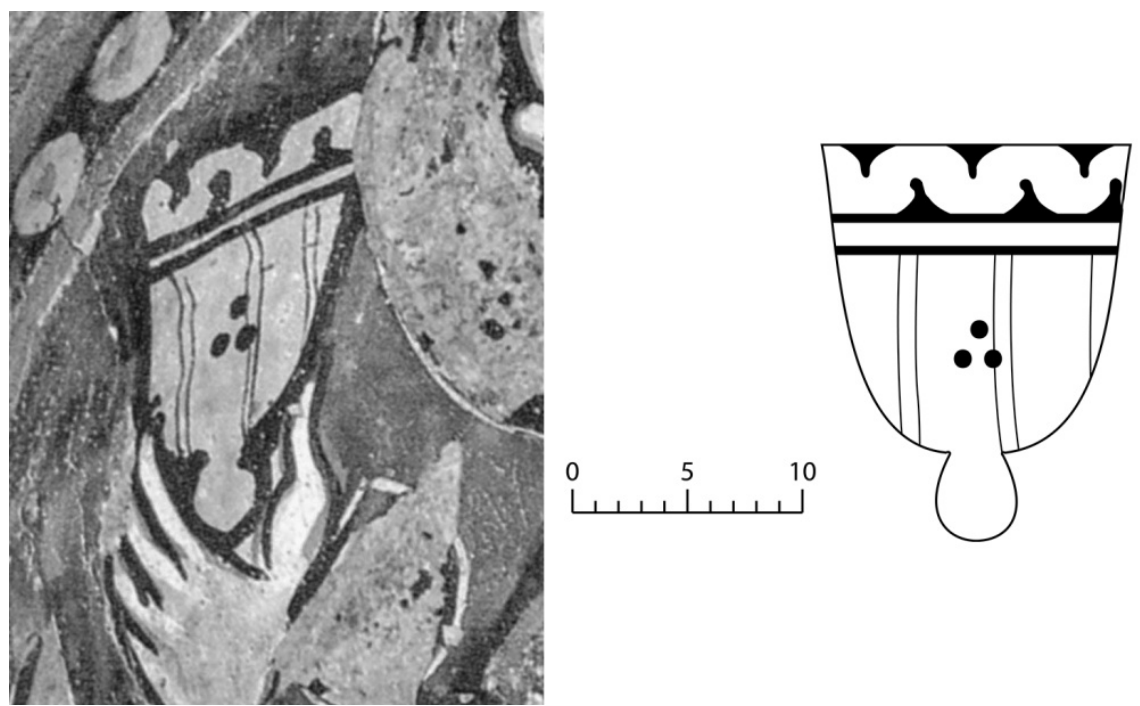

Fig. 13a-b - Goblet with peduncle cat. 84, nave. Detail from the original painting (left; after Brenk ed. 2010, fig. 769) and drawing (right).
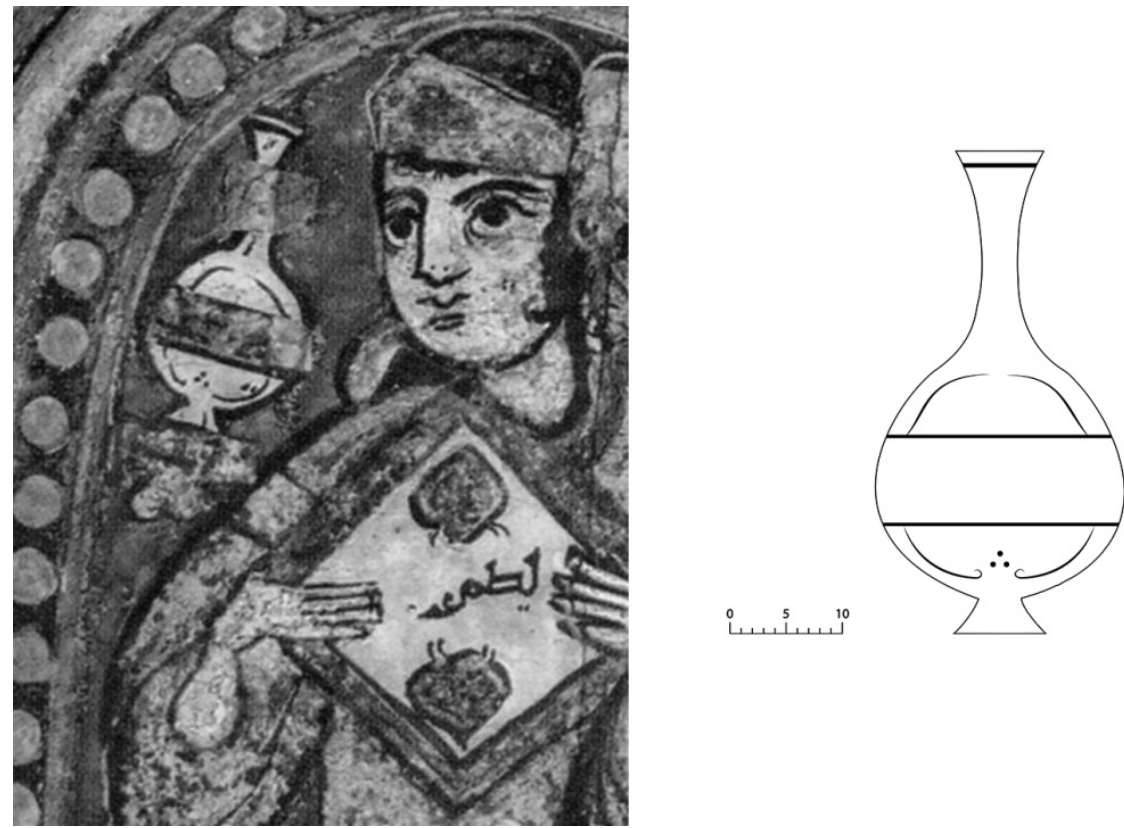

Fig. 14a-b - Bottle cat. 157, nave. Detail from the original painting (left; after Brenk ed. 2010, fig. 704) and drawing (right). 
XIX (2015) Preliminary notes on the ware depicted on the ceiling of the Cappella Palatina in Palermo
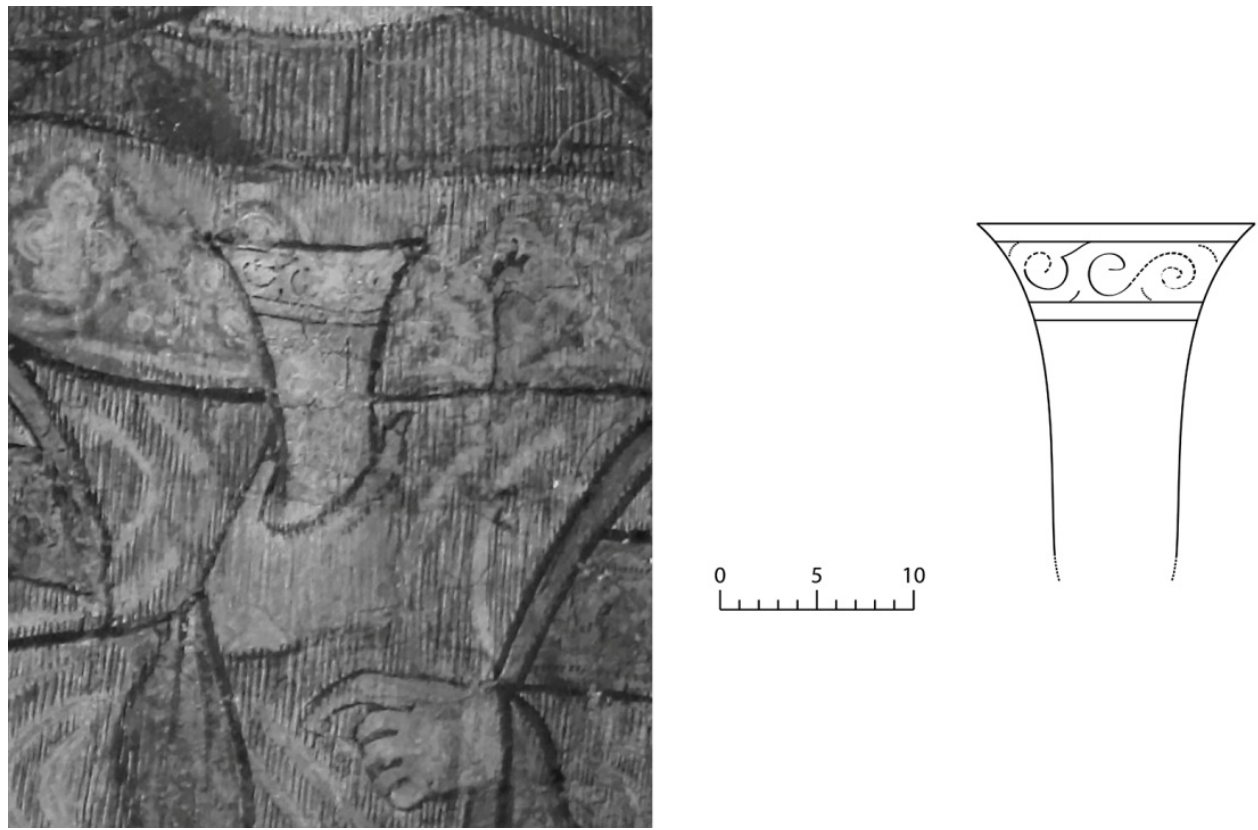

Fig. 15a-b - Glass cat. 56, north aisle. Detail from the original painting (left; photo (C) Francesca Anzelmo) and drawing (right).
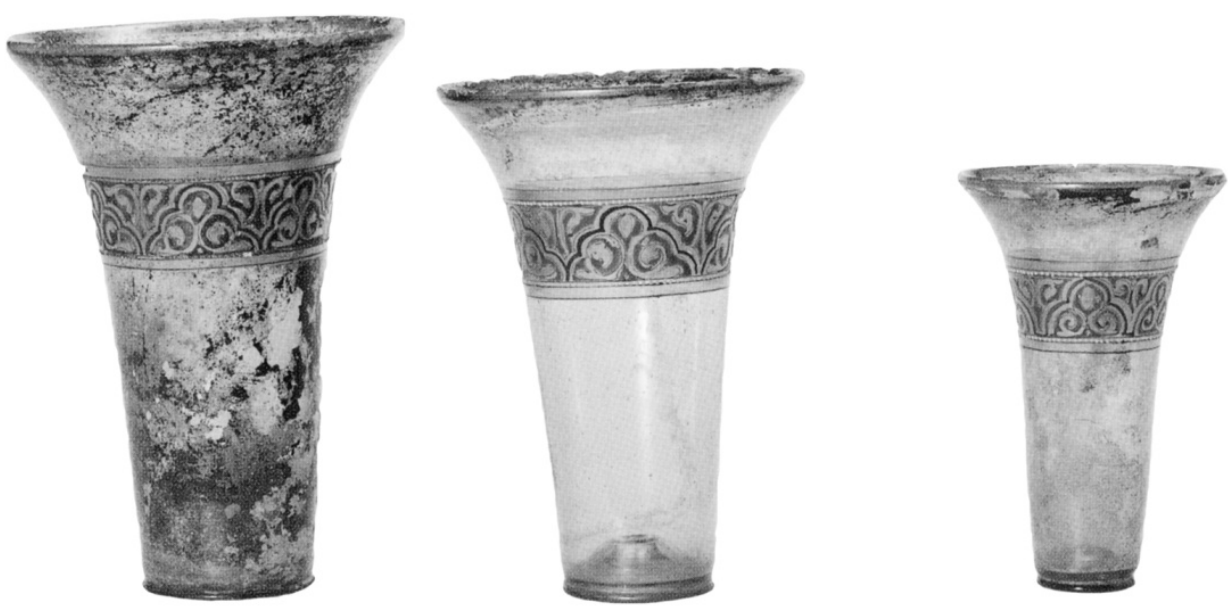

Fig. 16 - Ayyubid or Mamluk glasses, $13^{\text {th }}-14^{\text {th }}$ century, London, The Nasser D. Khalili Collection of Islamic Art, inv. GLD 578a, 578b, and 578c (after Nassar 2001). 


\section{SOMMARIO}

DipartimENTo SCIENZE DELl'ANTICHITÀ

SEZIONE di ORIENTALISTICA

\section{VICINO ORIENTE \\ XIX - 2015}

L. Nigro - Bethlehem in the Bronze and lron Ages
in the light of recent discoveries by the Palestinian MOTA-DACH

$\checkmark$. Pisaniello - Parallel passages among Hittite-Luwian rituals:

for the restoration of $K U B 35.146$

F. Spagnoli - Una testa di sileno in bronzo da Mozia

N. Chiaren

dall Area sacra del Kothon a Mozia

G. Labisi - al-Fudayn: an Umayyad residence in Northern Jordan

P. Buzi - Early Christianity in the Fayyūm: the new contribution of archaeology

I. Materia - Preliminary notes on the ware depicted on the ceiling

of the Cappella Palatina in Palermo

S. Autiero - Indian Ocean trade:

a reassessment of the pottery find
$\left(3^{\text {rd }}\right.$ century $B C-S^{S^{t h}}$ century $\left.A D\right)$

M.M. Jamhawi - N. Al-Shakarchi - I. Al-Hashimi

Assessment of tourists' satisfaction in the downtown of Amman

SCAVI E RICERCHE

L. Nigro - C. Fiaccavento - M. Jaradat - J. Yasine

A

L. Nigro - D. Montanari - M. Ghayyada - J. Yasine

A Middle Bronze and Iron Age necropolis near Bethlehem (Palestine)

L. Nigro - G. Ripepi - I. Hamdan - J. Yasine

15 Interim Report

and valorization of archaeological heritage

R. Francia - L'archivio di tavolette del complesso B-C-H di Büyükkale

organizazione degli archivi reali ittiti. Considerazioni preliminari

V. Pisaniello - La collezione di tavolette del complesso B-C-H di Büyükkale

T. De Vincenzi - L'archivio di tavolette del complesso B-C-H
sull'acropoli di Büyükkale

Museo del Vicino Oriente, Egitto e Mediterraneo

L. Nigro - Il nuovo allestimento del Museo del Vicino Oriente,

Egitto e Mediterraneo della Sapienza

D. Montanari - Bollettino delle attività del Museo del Vicino Oriente,

Egito e Meditraneo della Sapienza, anno 2015

RECENSIONI

A. Orsingher - E. PAPPA (2013), Early Iron Age Exchange in the West:

(Ancient Near Eastern Studies Supplement Series 43)

Leuven - Paris - Walpole 2013, MA.: Peeters $\frac{1}{2}$

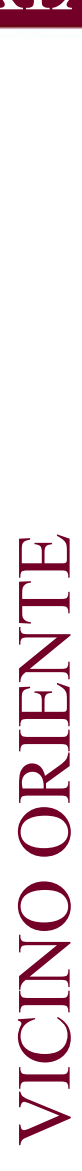

345

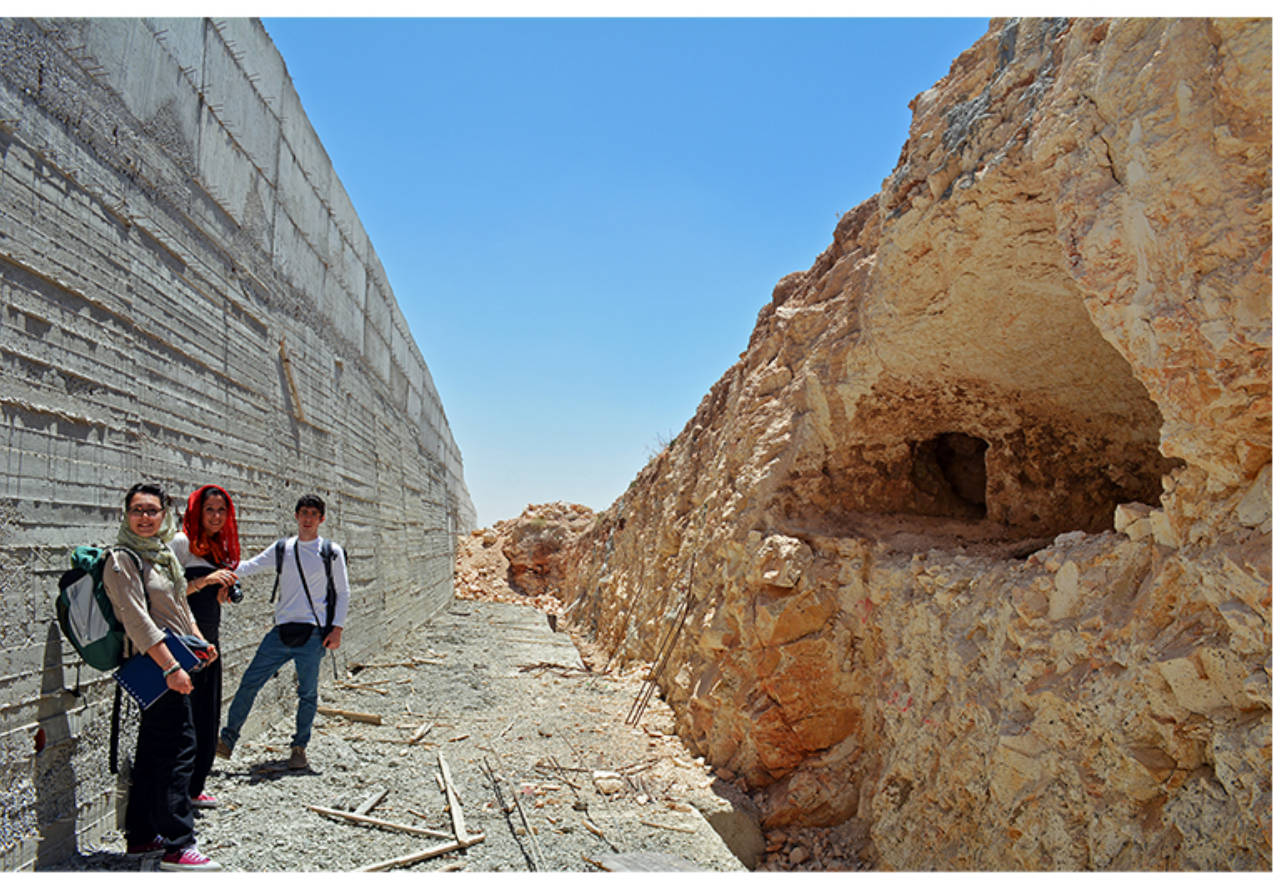

ROMA 2015 


\section{VICINO ORIENTE XIX - 2015}


VICINO ORIENTE

SAPIENZA UNIVERSITÀ DI ROMA

DIPARTIMENTO SCIENZE DELL'ANTICHITÀ

SEZIONE DI ORIENTALISTICA

Scientific Editor: Lorenzo Nigro

International Scientific Committee: Brian Rose, Frank Braemer, Mounir Fantar, Piero Bartoloni, Thomas Schaefer, Zeidan Kafafi

National Scientific Committee: Carlo Giovanni Cereti, Maria Vittoria Fontana, Sebastiano Tusa, Massimiliano Marazzi

Editorial Board: Daria Montanari, Chiara Fiaccavento

Tipografia: SK7 - Roma

ISSN 0393-0300

Rivista con comitato di referee

Journal with international referee system

www.lasapienzatojericho.it/SitoRivista/Journal/Rivista.php

In copertina: Tomba B9, necropoli di Khalet al-Jam’a (Betlemme). 
VICINO ORIENTE

SAPIENZA UNIVERSITÀ DI ROMA

DIPARTIMENTO SCIENZE DELL'ANTICHITÀ

SEZIONE DI ORIENTALISTICA

\section{SOMMARIO}

ARTICOLI

L. Nigro - Bethlehem in the Bronze and Iron Ages

in the light of recent discoveries by the Palestinian MOTA-DACH

V. Pisaniello - Parallel passages among Hittite-Luwian rituals:

for the restoration of KUB 35.146

F. Spagnoli - Una testa di sileno in bronzo da Mozia

N. Chiarenza - Una matrice per terrecotte con sileno dall'Area sacra del Kothon a Mozia

G. Labisi - al-Fudayn: an Umayyad residence in Northern Jordan

P. Buzi - Early Christianity in the Fayyūm: the new contribution of archaeology

I. Materia - Preliminary notes on the ware depicted on the ceiling

of the Cappella Palatina in Palermo

S. Autiero - Indian Ocean trade:

a reassessment of the pottery finds from a multidisciplinary point of view ( $3^{\text {rd }}$ century $B C-5^{\text {th }}$ century $\left.A D\right)$

M.M. Jamhawi - N. Al-Shakarchi - I. Al-Hashimi

Assessment of tourists' satisfaction in the downtown of Amman

SCAVI E RICERCHE

L. Nigro - C. Fiaccavento - M. Jaradat - J. Yasine Archaeology from A to Z: Abu Zarad, an ancient town in the heartland of Palestine

L. Nigro - D. Montanari - M. Ghayyada - J. Yasine

Khalet al-Jam'a. A Middle Bronze and Iron Age necropolis near Bethlehem (Palestine) 185 
VICINO ORIENTE

SAPIENZA UNIVERSITÀ DI ROMA

DIPARTIMENTO SCIENZE DELL'ANTICHITÀ

SEZIONE DI ORIENTALISTICA

L. Nigro - G. Ripepi - I. Hamdan - J. Yasine

The Jericho Oasis Archaeological Park - 2015 Interim Report.

Italian-Palestinian Cooperation for protection

and valorization of archaeological heritage

R. Francia - L'archivio di tavolette del complesso B-C-H di Büyükkale

e l'organizzazione degli archivi reali ittiti. Considerazioni preliminari

V. Pisaniello - La collezione di tavolette del complesso B-C-H di Büyükkale

T. De Vincenzi - L'archivio di tavolette del complesso B-C-H sull'acropoli di Büyükkale

Museo del Vicino ORIente, Egitto e MediterRaneo

L. Nigro - Il nuovo allestimento del Museo del Vicino Oriente,

Egitto e Mediterraneo della Sapienza

D. Montanari - Bollettino delle attività del Museo del Vicino Oriente,

Egitto e Mediterraneo della Sapienza, anno 2015

\section{RECENSIONI}

A. Orsingher - E. PAPPA (2013), Early Iron Age Exchange in the West:

Phoenicians in the Mediterranean and the Atlantic

(Ancient Near Eastern Studies Supplement Series 43),

Leuven - Paris - Walpole 2013, MA.: Peeters 